\title{
COMMUNITY EMPOWERMENT IN THE DEVELOPMENT OF MANGROVE TOURISM IN BATU KARAS OF PANGANDARAN, WEST JAVA
}

\author{
Agustina Eka PUTRI \\ University of Padjadjaran (UNPAD), Master of Sustainable Tourism School of Postgraduate, \\ Jl. Bandung-Sumedang KM 21 Jatinangor Indonesia, e-mail: agustina19001@ mail.unpad.ac.ic \\ Ute Lies Siti KHADIJAH* \\ University of Padjadjaran (UNPAD), Master of Sustainable Tourism School of Postgraduate, \\ Jl. Bandung-Sumedang KM 21 Jatinangor Indonesia, e-mail: ute.lies@unpad.ac.id
}

\section{Evi NOVIANTI}

University of Padjadjaran (UNPAD), Master of Sustainable Tourism School of Postgraduate, Jl. Bandung-Sumedang KM 21 Jatinangor Indonesia, e-mail: evi.novianti@unpad.ac.id

\author{
Citation: Putri, A.E., Khadijah, U.L.S., \& Novianti, E. (2020). COMMUNITY EMPOWERMENT IN THE DEVELOPMENT OF MANGROVE \\ TOURISM IN BATU KARAS OF PANGANDARAN, WEST JAVA. GeoJournal of Tourism and Geosites, 31(3), 972-978. \\ https://doi.org/10.30892/gtg.31306-529
}

\begin{abstract}
This article discusses community empowerment activities in coastal areas whose citizens experience poverty problems. The problem that arises in Batu Karas Village is the lack of development and the lack of empowerment of the surrounding community. Mangro ve tourism is open enough to be used as a field for economic improvement for mangrove tourism-based communities. Batu Karas Village has a strategic coastal area. However, the conditions in Batu Karas Village have some things that cause socio-cultural aspects and sociological aspects that cannot be considered so that it needs the development and empowerment of various aspects, both from the local government and other interested parties. The purpose of this research is to find out the model carried out by the local community in the effort to develop mangrove tourism in Batu Karas Village, find out what strategies the local government should carry out, and find out what the government implemen ts in developing and empowering the community in the field of mangrove tourism. This research uses the theory of community empowerment, which is a series of activities to strengthen the power or empowerment of weak groups and communities, including individuals who experience povert y. In this study, the researchers used qualitative methods. Information regarding research is obtained from data collection techniques of observation, interviews, and documentation, as well as other methods related to research studies. This research found that community empowerment and development in tourism is said to be sufficient to have an impact on the economic level of rural tourism communities, especially in the presence of support from the local government and related parties who pay more attention to the mangrove area.
\end{abstract}

Key words: ecological awareness, social empowerment, mangrove tourism, West Java

\section{INTRODUCTION}

The study of the preservation of nature for nature itself has become a hallmark of ecological awareness lately (Patrício, 2018). Here, nature is treated as having its own intrinsic that must be respected by humans (Zohreh and Syed Mohammad, 2018). It also appears here that humans must serve nature (Barbieri et al., 2011). However, giving to nature in addition to giving to local residents is among the new things that must be preserved. This is because there includes aspects of the involvement and pragmatism of local residents. Some call this a social ecology (Bookchin, 2007). So that nature and humans are not isolated from each other. This is one form of nature-based local tourism.

In Indonesia, tourism was initially seen as more than just an economic activity, both for the community and the country (Abdul, 2018). As with development in general, some things cause socio-cultural or sociological aspects to get less attention. Tourism involves the government and society (Cohen and Cohen, 2012). Indonesian government wants that the development of tourism received particular attention so that it can increase its income (Kasdi et al., 2019). For, in a world atmosphere that is still gloomy, where exports of goods meet various obstacles, tourism could boost economic development (Perbawasari et al., 2019). Tourism should also be able to encourage people to participate in development to achieve the desired welfare goals (Tribe, 2015) actively. This opinion put forward, considering that in social life in Indonesia, the interpretation of various activities is now dominated by a development-oriented perspective. So it is not uncommon that development that emphasizes the interests of the people (people-oriented) is overlooked, and human values (humanism) are ignored (Bankoff, 2013). Most Indonesian people live in rural areas close to the maritime coast. In those rural areas, the potential of human resources and the potential of natural resources are located (Dian et al., 2018). If it is linked between the community as the main actor of development and the main potential in the village, the village has a vital role. Development orientation that focuses on rural areas is a very strategic action because directly or indirectly, this will have a positive and extensive impact (Santoso et al., 2019). The existence of a mangrove tourism village is like an oasis for urban communities. Amid an increasingly crowded city environment plus worrying pollution levels, the need to enjoy the beautiful environment and breathe fresh air is a must. Mangrove tourism village offers an adventure that can be fun but also invites visitors to be aware of a healthy and natural environment (Sprague, 2019).

Enjoying the green atmosphere of the countryside with all its traditional activities can be an effective way of self-refreshment, especially for those who are busy with their daily routine. For the village community, the development of the village concept as a mangrove tourist attraction will have a positive impact, especially in terms of the economy. At least add to the income of its citizens. Independent mangrove tourism villages can be realized simply by relying on natural resources and local human resources (HR) (Scheyvens and Hughes, 2019).

The surrounding community can improve micro small and medium enterprises (MSMEs) independently as well, for example, by making handicrafts as souvenirs that are sold to visitors. It can make his home as a homestay of tourists who come to his vil lage. The

\footnotetext{
${ }^{*}$ Corresponding author
} 
beautiful nature of the community has its advantages, meaning that each region has the potential to be developed into a touri st village (Sen and Walter, 2020). However, the development of a tourism village requires coordination and cooperation. It also requires a balanced role between elements of stakeholders, including the government, the private sector, and the community. Therefore one approach that can be used to develop rural tourism is participatory (Rodrigues and Prideaux, 2018). The most critical essential in the development of a tourism village is the involvement of the village community in every aspect of tourism activities in the village. Two critical indicators of the many indicators regarding the success rate of a tourism village are: first, the independence of local institutions and, secondly, the availability of adequate human resources in carrying out tourism development (D'Lima et al., 2018). The independence of local institutions is significant because as a basis for community activities in tourism, which serves to be a source of economy, accumulation of knowledge and skills, and cultural heritage of the local community (Gorbuntsova et al., 2019).

Meanwhile, the availability of visionary, reliable, and professional human resources will also be a key factor supporting the success of the programs themselves. The formulation of the development planning model here is, of course, determined by the laying of the necessary vision and mission. The views and goals far ahead of the development of a tourist village are the creation of an independent and empowered rural community in the social, economic, and cultural fields. Empowerment can be achieved by providing the broadest possible opportunity for them (villagers) as the subject of development to manage themselves with natural resources, human resources, and the tools they have for shared welfare (Monteiro and de Noronha, 2020). Community empowerment is the process of making people or communities who have the capacity or ability to do something even under pressure, obstacles, or domination of power. Human resources are the main supporting element in the development process in addition to natural resources and technology (Corrêa Cavalieri \& Neves Almeida, 2018).

The case to study regarding this community empowerment is Pangandaran Regency. Pangandaran Regency is a district that has much natural beauty of mangrove tourism so that the people already know enough and take advantage of its beauty and beauty to roll out the tourism industry. One district has a lot of mangroves tourism. Pangandaran Regency is a district in the Province of West Java, Indonesia. The capital city is Parigi. This regency is bordered by Ciamis Regency and Banjar City in the north, Cilacap Regency in the east, the Indian Ocean in the south, and Tasikmalaya Regency in the west. Pangandaran is the name of a village, the name of a district, and the name of a tourist attraction. Pangandaran is located in the southeastern part of West Java Province, a distance of about 200 KM from Bandung and directly adjacent to Cilacap Regency, Central Java. Pangandaran southern part directly adjacent to the Indian Ocean or people used to call the south coast (Pangandaran Regency Government, 2020). The area of the Pangandaran Regency is 168,509 Ha with a sea area of 67,340 Ha. Pangandaran Regency has a beach length of $91 \mathrm{Km}$. The area of forest both confirmed and not yet covering an area of 28,898.73 Ha. PKPH / RPH Cijulang area has the largest forest area of 9,299.88 Ha, which spread in Cijulang, Parigi, Cigugur, and Langkaplancar sub-districts. The largest forest is in Gadung Mountain, Cigugur, which reaches 3,168.9 Ha. In addition to the forests managed by PKPH / RPH, there are also community forests totaling 31,707.44 hectares spread in 36 districts. The largest community forest is in Kalipucang District, which is 3,599 Ha. The majority of people's livelihoods of Pangandaran are fishermen because the waters of Pangandaran have potential fishing that promises to Pangandaran people. Besides fishers, Pangandaran people also have many livelihoods for farmers. The rest is engaged in tourism, trade, private employees, and others (Pangandaran Regency Government, 2020).

The most significant potential of the Pangandaran Regency is tourism, both beach, and river attractions. There are many favorite attractions both by foreign and domestic tourists. Attractions in Pangandaran Regency are Pangandaran Beach, Nature Tourism Park (Pananjung Nature Reserve), Batu Hiu Beach, Batu Karas Beach, Madasari Beach, Karapyak Beach, and river tourism namely Cukang Taneuh (Green Canyon), Citumang, and Santirah. Hotel facilities are available with various classes and quite complete restaurants and other entertainment venues around these locations (Pangandaran Regency Government, 2020). One of the sea and beach tourism destinations in Pangandaran district is Batu Karas tourist beach. Batu Karas is one of the districts and villages that have beautiful beaches, so this Batu Karas village has bright prospects in terms of sea and beach tourism. So, to prepare human resources and other supporting sources, local government efforts must develop and empower prospective sea and beach tourism conditions. Based on these problems, the authors are interested in investigating more deeply regarding the model of community development and empowerment in the field of marine and beach tourism located in the village of Batu Karas, Cijulang Subdistrict (Pangandaran Regency Government, 2020).

The basic unit of social action is that the involvement of each individual is very supportive in development (Privitera et al., 2018). In the case of tourism object development, such as the development of mangrove tourism, individual involvement is urgently needed. With the development of tourism, each individual in the community tries to empower themselves through economic activities aimed at tourists so that they can supplement their income (Eshun \& Tichaawa, 2019). Everyone has their way of developing themselves according to their abilities.

Thus if community development succeeds in empowering community members following the conditions of tourism in their area and the situation is favorable for them, then the community will carry out various activities according to their social behavior. Potential tourism, among others, tourist attractions, tourist activities, accessibility, and transferability of the Batu Karas village, have a high selling value. By developing mangrove tourism and turning Batu Karas into a Tourism Village, this will have a direct impact on the Batu Karas village community. The development of the Batu Karas coastal mangrove tourism will support efforts to grow entrepreneurial potential, diversify tourism products, sustain the economy of the local community, preserve and sustain natural resources in rural areas, and revitalize local culture.

So the development of mangrove tourism for community empowerment in the village of Batu Karas is started from the tourism potential in the village of Batu Karas which was developed into one of the Objects and Attractions, namely mangrove tourism by tourism actors, among others: local communities, village governments, sub-district governments, district governments, tourists and the private sectors (Batu Karas Village Government, 2020). In implementing the development of tourism villages both by the government, the community, tourists, and the private sector, there are several supporting factors (tourism potential) and obstacles (policies, budget, resources). The development of the Tourism Village will have an impact on the people of Batu Karas Village, so that it will make the community more capable and independent to make their condition better (Batu Karas Village Government, 2020). Mangrove tourism development needs to be based on a comprehensive concept that can accommodate all aspects that support the optimization of resources, especially human resources owned by the village.

\section{MATERIALS AND METHODS}

The method used in this research is qualitative, for the objects in this research are natural objects as in typical situations that not manipulated the conditions, so this method is also called the naturalistic research method (Bernard et al., 2016). Also, this research is qualitative in the sense that it is fundamentally dependent on human observations in their region and relates to these people in their language, their lives, and their interactions with their world around them (Miller \& Kirk, 1986) (Corbin \& Strauss, 2014). Like a descriptive research, this research describes the ongoing problems of the situations or events that are taking place in the field. Neuman (2014) explains that descriptive research is the accumulation of primary data in the way of describing merely not needing to find or explain interconnected, tested hypotheses, make predictions or obtain meaning and implications, even though research aims to find these things and include descriptive methods. 
Primary data collection techniques such as odd jobs in tourist sites in Cijulang Subdistrict, Pangandaran Regency, are through observation, as well as in-depth interviews. Library studies used to discover secondary data such as theories, views, research results, books, and other archives, documentation. Observation is a way to retrieve data using the eyes without the help of other standard tools for this purpose. Field research can also be considered as a comprehensive approach in qualitative research or as a method for collecting qualitative data. The researchers go to the field to make observations about a phenomenon in a natural state or "in situ" (Adriansyah et al., 2015). The researchers conducted various observations to obtain data directly from primary sources, correctly to see the situation of a location, a life, the atmosphere of life, and to participate in various activities. The observations used in this study are observation of participation and nonparticipation that is adjusted to the object or target being observed. Participatory observation is an observation made with the observer directly involved actively in the object under study. So in conducting this research, the researchers will go directly to the location of the study to review and observe the problems that will be actively investigated by the researchers together.

The interviews were aimed at the community around mangrove tourism. The interviews also took place between the observations involved. In this case, the researchers were directly involved in the activities of the research subject. The researchers participated in community activities while asking questions about the research problem so that the researchers got corroborating data when making observations involved. To obtain maximum data, the researchers interviewed the government involved in the development of the Batu Karas tourism village, including, Community Leaders, RT, RW heads, Village Heads, and related Tourism Offices. The interviews are expected to obtain maximum and valid data. After the collection of data, the next step was to analyze the data. Data analysis was the processes of systematically searching and compiling data obtained from the interviews, field notes, and the documentary by organizing categorical data, describing it into units, synthesizing and compiling the in the patterns, choosing what is essential and what will be learned, and made conclusions so that they were easily understood by themselves and others. The purpose of research in data analysis was to narrow down and limit the findings to become one data that was more meaningfully ordered and organized.

The data analysis process begins by examining all available data from various sources, namely from interviews, observations that have been written in field notes, personal documents, and official documents. The data is a lot of about a myriad. After reading, studying, and analyzing, the next step is to conduct data reduction, which is carried out by doing abstractions. Abstraction is an attempt to make a summary of the core, process, and statements that need to be maintained so that it remains in it.

The next step is to arrange them in units. The unit is then categorized in the next step. The category was created while coding. The final stage of this data analysis is to conduct a data validity check. After completing this stage, the data interpretation process in processing interim results becomes a substantive theory by using specific methods. The study was conducted in Cijulang Subdistrict of Pangandaran Regency. In the area, there is a tourist attraction frequently visited by tourists from various regions, local and foreign. The tour is called Batu Karas beach. This location is made into a research site because this place has many resources to be used as economic change for development and empowerment to increase mangrove tourism in Batu Karas Village.

\section{RESULTS DISCUSSIONS}

\section{Mangrove Tourism in Batu Karas}

Village Pantai Batu Karas Village is no less potent than other regions in Pangandaran Regency. For this reason, this sector is essential to be developed, tourism is directed to tourism that is environmentally friendly and orderly and comfortable so that the potential utilization can be maximized. Tourism in the coastal areas of Batu Karas Village Beach is a potential sector to be developed. The many coastal ecosystems, such as coral reefs that are still good and the quality of the waters that are still good is the potential for mangrove tourism that needs to be managed professionally.

Based on the potential of natural resources and the environment of the coastal area of Batu Karas Village, the type of tourism suitable for development is mangrove tourism. Mangrove forest here is indeed beautiful, even though it is not yet famous compared to other tourist destinations such as Green Canyon, Citumang, Santirah, and the like. Nevertheless, in terms of cost is very affordable and very cheap so that it can be used as a reference when vacationing in Pangandaran. Mangrove tourism in Pangandaran recently opened and published so that there are still many promotions from the government local. Batu Karas Mangrove Forest located in Sanghyang Kalang Hamlet, Batu Karas Village, Cijulang District, Pangandaran Regency, West Java, which is the Cijulang River Estuary which is directly related to the sea (Indian Ocean). The effects of tides are very clearly visible. Batu Karas Mangrove Forest is known as the Batu Karas Mangrove Restoration and Learning Center. As for the area of 20 hectares, there are various types of mangroves ranging from Bruguiera exaristata, Parviflora, Rhizophora mucronata, Rhizophora apiculata, Avicennia alba, Avicennia marina, Bruguiera gymnorhiza, to Sonneratia alba. The Greening process continues to be carried out gradually along the coast in Pangandaran until now.

The Batu Karas Community Supervisory Group (Pokwamas) of Pangandaran Regency, has a duty as the Maritime and Fishery Resources Supervisor, including overseeing the conservation of mangroves, coral reefs, sea turtles and others, under the auspices of the Forestry, Agriculture and Maritime Affairs of Pangandaran Regency. Since December 2013, the Marine Resources and Coastal Community Empowerment Section with Pokwamas had begun to identify mangrove areas. One of the existing mangrove forests is in Cikalapa Block, Batu Karas Village, Cijulang District, Pangandaran Regency. The existence of this Batu Karas PRPM is expected to be a conservation area, and it is also expected to be a tourist attraction so that more tourists come to Pangandaran Regency. PRPM Batu Karas can be reached from 4 places. PRPM Batu Karas is the easiest to reach from Batu Karas Beach. In addition, it can also be reached from Green Canyon Pier, Nusawiru Airport, or Bojong Salawe (Interview with US, 1/8/2020).

\section{The Community Empowerment Model in the Mangrove Tourism}

Batu Karas Village administratively located in West Java Province, namely in Cijulang Subdistrict, Pangandaran Regency. Pangandaran Regency has quite diverse natural resource potentials, including the Pangandaran Regency Region, which has a full sea, beach, and coastal area. Besides being a potential area for fisheries development, the south coast area of Pangandaran Regency is also very potential for tourism development. Sea and beach tourism in the village of Batu Karas is included in the Ecotourism section of the Cijulang Pangandaran bay. By having a sea and beach area which is owned by the Pangandaran Regency Government, the Pangandaran Regency Government is optimally trying to empower the communities that are around the coast and the sea. Based on the results of interviews with the local government that the government's efforts in empowering the community in the field of mangrove tourism in Batu Karas Village refer to Rule of Village (Peraturan Desa -Perdes) No. 5 of 2014 concerning the development of Tourism Villages in CHAPTER XI article 26 namely, that the village administration prioritizes the concept of community empowerment in order to facilitate and carry out efforts to develop tourist villages. The development is carried out in a coordinated and integrated manner, with the principle of transparency, participatory, and accountability, as well as reflecting the socio-cultural values that exist and develop in society. In the implementation and preservation and management of 
village tourism, a Community Organization for coastal and marine tourism was formed. So in this Batu Karas village, the role of the youth organization is actively participating in community empowerment efforts. Community Organization in the Field of Tourism is the right partner of the local government, starting from RT, RW, Village, Subdistrict, and Tourism Office.

Based on an interview with Mr. TS, as a Counselor from the Tourism Office, he said that in carrying out community empowerment in Batu Karas Village, Cijulang District, Pangandaran Regency, namely providing socialization and training in the Development of Rural Creative Economy Business (PUEKP) continuously, which is one month once in carrying out empowerment to the tourism-based community with various abilities such as the ability to run a business, marketing, home industry, and others (Interview with TS, 1/8/2020).

Based on an interview with Mr. MN as the Chairperson of Youth as well as administrators of the implementation of the PUEKP it was found that there were activities that support the Development of Rural Economic Enterprises (PUAP), namely through socialization and training in the PUEKP to the community (Interview with MN, 8/1/2020).

Mr. SL, as a member of the youth group in the Tourism Village said that he had participated in the socialization and training in the PUEKP, which is done once a month in order to improve business capabilities. Mrs. ST, for example, considers that home industry training is beneficial for mothers to increase family income (Interview with SL and ST, 1/8/2020). While from Mr. DT added that in carrying out community empowerment in Batu Karas Village, Cijulang District, Pangandaran Regency, namely providing socialization and training in the PUEKP continuously, which is once a month in carrying out empowerment to the community (Interview with DT, 1/16/2020).

It appears that community empowerment happened in the lower layers or disadvantaged layers of society that are considered to be oppressed by the system and in the social structure, which is liberated by people's involvement in the development. In the Batu Karas community, this empowerment effort consists of several aspects, namely: (1) Awareness about increasing the ability to identify problems or problems that cause life difficulties and suffering experienced by the community; (2) Awareness about weaknesses and potentials rises to and increases confidence in the community to get out of problems and to solve problems and develop the community;

(3) Enhancing the management capabilities of existing resources (Anderson and Woodrow, 2019).

Batu Karas Village followed the procedures to empower the community. The procedures carried out in empowering the people's economy based on the theory of empowering are: first, generating (enabling). In general, powerlessness occurs because the potential is not recognized. The process is enabling carried out to arouse the will of the people who are heavily influenced by their perceptions and knowledge of themselves and their environment. Second, empowering, at this stage, aims to make people become able or even more capable of being equipped with the knowledge and material assistance. Third, protection, the process of strengthening or protecting the community by providing a solution for some of the difficulties encountered (Zamenopoulos et al., 2019).

Thus, the meaning of community empowerment can be concluded that community empowerment should not make the community dependent on gifting programs, but everything that is enjoyed must be produced on its efforts. The result is independent of the community and builds the ability to advance them towards life better in a sustainable way. The people of Batu Karas practiced this. The strategy called bottom-up means that the community is involved from the beginning in the planning process to the implementation and maintenance of development results. It is because the community itself knows about their needs and how to fulfill them (Bryson, 2018).

The real model carried out by the government in the efforts to develop Rural Creative Economy Enterprises (PUEKP) includes life skills training. This training is one of the efforts to mobilize community activities for young people that are given the freedom to play an active role in advancing mangrove tourism activities. Life skill training is carried out by involving all elements of the village apparatus, from the RT, RW, Youth Organization, and Village Government level without exception. The training is entrepreneurial life skill training in the form of a creative economy. The training is expected to open insight into the surrounding community in carrying out local economic activities, such as making handicrafts related to tourism, such as souvenirs, opening restaurants, selling t-shirts that read coastal mangrove tourism.

The village administration fully manages economic activities through youth clubs. Hence, youth organizations are required to have innovative, creative programs based on the local wisdom of the local culture. It is to increase economic empowerment and welfare in the community. The government actively encourages the community to devote all the abilities and expertise possessed by the local community in the form of handicrafts managed professionally through the Village Unit Cooperative (KUD) as a forum for the work of the village community. Another model that is carried out by the government in empowering existing communities in the coastal and marine tourism environment, the government also trains soft skills in the form of expertise in advertising mangrove tourism. The purpose of advertising mangrove tourism is that tourists can get information from the internet or other social media. Hence, more and more visitors coming to the tourist beaches in Batu Karas, so that it will affect the economic income of the community as well.

Another benefit of the community's expertise in the field of IT will be to boost the market for the creative results of society advertised through social media, which today has a profound effect on the people's economy.

\section{Local Government Strategy}

Development of community capacity (community empowerment) can be pursued with a variety of strategies that are tailored to the conditions and various potentials that exist in the local community. Improving education is an effort to increase community knowledge and skills under the required field of expertise. Education does not always have to have a formal nuance, but it can also be set forth as a nonformal education approach. It is performed for example, through trainings, field practices, internships, comparative studies, and the like.

Besides, counseling is one of the examples of non-formal education where the discussion of the material is very flexible (adapted to the needs of the target), counseling is applied to the adult education system with the target being people who already have much experience in their fields. Then, to help the community find their potential to overcome the problems faced is a community outreach program. Community assistance activities are to bridge the community to be better able to access various needs, both material and non-material. Here the assistants act as facilitators to stimulate the search and implementation that are to solve the problems and obstacles faced by the community. Assistance staffs also facilitate bringing the community closer to various accesses, for example, access to information, access to capital, law, and various facilities intended to develop productive community businesses.

Two central problems can cause a lack of access to the information needed by the community. First, because the information is still exclusive (intentionally information is not disseminated to the public, except with certain sacrifices such as information on the internet, information that is in the Indonesian Business Data Center, the information in various government agencies that are not disseminated (Tayyiba, 2015). The lack of public access to this type of information needs to be assisted by the government to further socialize "expensive" information to the public, for example through brochures, periodicals, radio and television, such information as related to superior products, sources of raw materials, and marketing information. Second is the weakness of the community itself in accessing information that is already available in their environment, and this can be caused by low community motivation to access the information or community limitations due to illiteracy and technological blindness with the campaign the importance of information for the community. 


\section{Empowerment of Community Institutions}

Village community institutions that have been used as a means of tourism empowerment were cooperatives (such as the Village Unit Cooperatives-KUD). However, efforts to empower these two institutions have never been thoroughly carried out. Therefore, it is only natural that the empowerment of farmers takes place half-heartedly. The farmers or villagers are statistically the most significant community group. On the other hand, we are also aware that so far, the government has hung the hope of fulfilling national food availability in the hands and shoulders of these farmers. This hope rose when farmers still overcame the storm of the economic crisis that worsened the enormous conglomerate. It is not only agriculture that still has a positive growth rate (though relatively small) compared to other economic sectors that have negative growth rates (Interview with BS, 5/1/2020). In the case of community development, it is necessary to grow community production groups. The formation of groups is intended to combine the economic potential and various community resources, which will make it easier for the community to access various facilities for the development of productive community activities. The formation of groups is also intended to increase the "bargaining position" in various interests, for example, for the efficiency of production and to increase the marketability of products (Interview with DD, 1/1/2020). Regarding economic strengthening, the empowerment of cooperatives is a necessary thing in the community with a mangrove tourism background. Institutional empowerment of cooperatives can be done by developing and strengthening existing cooperatives or growing ones that do not yet exist but have the potential to be raised (for example, the development of farmer-fishermen groups into farmer-fishermen cooperatives). The development and strengthening of cooperatives require a variety of action programs that include aspects of applying the principles of cooperatives, organizational development and management of cooperatives, business, and capital development, and fostering cooperatives. There are efforts to strengthen the cooperative base, namely the application of the principles of cooperatives, the development of cooperative organizations, and the development of businesses and capital.

The application of cooperative principles also requires concrete steps (1) fostering cooperative independence by reducing government intervention; (2) functioning member meetings as a means of business decisions; (3) increasing the insight and understanding of coaches, members, and the community, so that the principles and enthusiasm and spirit of cooperatives can be applied thoughtfully and consistently; (4) cooperative socialization for the wider community (children) in the form of continuous cooperative advocacy; (5) cooperative consultation for management, managers and all members of cooperatives (Interview with CS, 5/1/2020).

The development of cooperative organizations can be done by (1) facilitating the permission and the process of establishing cooperatives (now facilitated); (2) improving the quality of human resources in the form of education, training and apprenticeship (for management, managers) on business management and entrepreneurship; (3) clarity of duties and responsibilities of management and managers; (4) cooperative organization restructuring; supplemented by the education division; (5) adopting modern management, for example the term cooperative management should be changed to a board of directors; (6) manager's qualifications on the basis of professionalism (education, good incentives and clear employment contracts) (Interview with BB, 1/1/2020). Business and capital development include: (1) increasing the ability of management and managers through training (entrepreneurial management, preparation of business plans and business feasibility); (2) recruiting professional managers to manage cooperative businesses based on business partnerships; (3) vertical integration of cooperatives (primary-secondary) such as Village Unit Cooperatives; (4) disseminating credit scheme information and access procedures.

Overall, an action program that fosters effective coordination between the PKM, Dekopin and PUDKUD Office of Manpower and Transmigration needs to be carried out, the addition of field workers (such as street vendors or independent workers) so that the development of small businesses and cooperatives can be intensive. The growth of cooperatives can be done by taking into account the groups that already exist in the community. A concrete example is a farmer-fishermen group (including women's groups), which has now been facilitated to become a farmer-fisherman cooperative. However, the realization is often still hampered by bureaucracy. An example is an extendedstanding permit, even though there are regulations about this. There is a person, but this must be realized and reformed for the advancement of cooperatives as the foundation of the people's economy in Indonesia (Interview with HD, 1/1/2020).

So far, it has been evident that potential human resources in the development of the agricultural sector are farmers, fishermen, and their families. Agricultural development would not have been possible without the active participation of farmers/fishers and their family members, including women farmers and fishers. The issues are: (1) How the people's economic empowerment program, in this case, cooperatives and small and medium enterprises (SMEs) can be formulated and implemented with a fairness approach; (2) How farmer women can play a role in increasing family income through cooperatives. Then how can the cooperation commitment realized with a spirit of continuity and not the origin for modest programs (Interview with DB, 1/1/2020)?

\section{Partnership Building Community}

Empowerments, through partnership efforts, can take place with bringing together business suitability between large entrepreneurs and businesses that develops in the community. Business sectors that can be developed through partnerships include various cooperation patterns, for example, the supply of raw materials, semi-finished materials, or finished materials that are mass-marketed by 'foster father.' Collecting partnerships also requires the presence of a Supporting Staff because between large entrepreneurs (foster fathers) and small entrepreneurs (communities), there are various gaps such as knowledge, capital, skills, management, and others. Assistance is needed to bridge the differences between the two partners. The efforts for this are (1) empowerment of the original community institutions which are proven to exist still; (2) multiplying the findings of appropriate technology in various aspects; (3) provision and improvement of facilities and infrastructure to support community life following the role that exists in the community, for example, repair of irrigation channels for farmers, the guidance of new technologies for traditional food artisans and the like (Interview with NS, 5/1/2020).

The function of government concerning empowerment is to direct the people to become independent. In this case, community empowerment means it cannot be released and handed over to the community concerned. Optimal community empowerment in order to be able to empower themselves to be better must be by involving the government optimally and deeply. Various models of community empowerment in the dynamics of its development, do not escape the role of government in empowering the community.

The role of the Government as a sub-district head is to prepare directions to balance development implementation (issuing regulations in the framework of the practical and orderly administration of development). As a regulator, the government provides an essential reference, which is then translated by the community as an instrument to regulate every empowerment implementation activity in the community. Economic empowerment of the community will be linked to policies that support the development of their businesses (Interview with DL, 1/1/2020). The Government, as the Village Head, is to mobilize multi-stakeholder participation when stagnation occurs in the development process. As a dynamist, the government plays a role by providing intensive and practical guidance and direction to the community. Guidance and direction are needed in maintaining dynamics. As a facilitator, the government tried to create or facilitate an orderly, comfortable, and safe atmosphere, including facilitating the availability of development facilities and infrastructure; so that it could bridge the interests of various parties in optimizing regional development (Interview with DD, 1/1/2020). 


\section{Empowerment of Local Communities}

In the end, the community itself decides whether to follow the progress and live with it or not. In an advanced system of life, the community must follow the progress. Otherwise, it will be irrelevant. It is primarily in a system offering services such as tourism. It is where the burden for local people is. They must master modern service tools and also have to adapt to get new jobs such as becoming a tourist guide, renting out comfortable seating facilities, selling items needed for visitors such as hats, renting umbrellas, mat, helping motorbike transportation, boat rental, and the like (Interview with LS, 11/1/2020). On the other hand, the ability to preserve the environment as a place for them to make a living, the mangrove forest, which is a tourist spot, becomes necessary. Here they must be able to carry out maintenance, for example maintaining mangrove plants themselves, maintaining road cleanness in the location of mangrove forests, and maintaining facilities that support the existence and access to the mangrove forests themselves.

In the world of tourism, communication is essential in forming networks between residents of tourist areas and between agencies that support tourism development. The problem of the production of the same tourism commodity among residents is no longer a problem because of the established communication. Hence, the villagers can make the best decision in the management of their businesses. Likewise, with other problems that develop with the existence of mangrove tourism, it can be overcome by communicating with one another. Especially considering that the existence of a place where people live is around the coast that changes day by day can be very drastic. So, this communication becomes essential. Things like the above are felt by the mangrove area maintenance groups and tourism business groups around the mangrove (Interview with DD, KK, and NN; 1/8/2020)

Therefore, to manage their tourism business, citizens need a variety of information in the field of tourism. Such information includes government policies, research results from various scientific disciplines, tourism experience from other places, as well as the latest information on market prospects related to tourism facilities, production, and services. They can get one of these information sources by access the internet as a source of information. Not only that, but they can also find out the latest information about the prospects of international markets related to production facilities and tourism products. However, the government is also obliged to provide counseling to farmers in realizing the quality of agricultural products (Interview with DD, 1/1/2020).

The government, tourists, and other stakeholders, including the general public, can also play a role as supervisors of the tourism village. The primary mission of the community must remain focused on maintaining the mangrove area. Thus, mangrove tourism is not solely based on economic activity alone. Based on the results of interviews conducted by the researchers, namely with NS that the activity of maintaining mangroves in the village of Batu Karas is now not merely an economic activity. More than that, the people of Batu Karas Village have assumed that managing mangrove tourism is a culture, namely a culture of nature preservation carried out by each member of the community. Likewise, because they have necessary work, some do trading, some raise even most of the people of Batu Karas Village go to the city to look for work in a city like Jakarta (Interview with NS, 5/1/2020).

Hence, this research states a theory that free and voluntary mangrove management could grow depending on the natural assets and the community (Scheyvens and Hughes, 2019; Carvache-Franco et al., 2019). The encompassing network can improve smaller scale small and medium ventures (MSMEs) autonomously, too, for instance, by making crafted works as trinkets that are offered to guests. It can make his home as a homestay of visitors who go to his town. The beautiful nature of the network has its points of interest, implying that every area can be formed into a vacationer town (Sen and Walter, 2020). Be that as it may, the advancement of a travel industry town requires coordination and participation just as a fair job between components of partners, including the administration, the private division, and the network. Along these lines, community participation in tourism industry can be utilized to create promising travel industry (Rodrigues and Prideaux, 2018).

Besides preserving mangrove forests, the community can also carry on a hereditary culture both in terms of food, clothing, games, and even traditional ceremonies. In turn, tourists can enjoy the presence of products and cultural activities by participating in using it both in terms of consumption, appreciation, and even now can be used as a place to upload to social media. It is where the existence of the mangrove forest has become a natural capital to become a tourist location and can provide blessings for the surrounding community. Thus, what happened in Batu Karas Village was the unification of the natural soul (Barbieri et al., 2011) as well as the outward human body, namely human pragmatism as an economic being (Tribe, 2015) as well as a natural being. This is what can be called as a social ecology, where humans preserve nature while benefiting from it (Bookchin, 2007). So here there is a mutual respect between humans and nature, as well as a mutual use.

\section{CONCLUSION}

Model conducted by the local government to empower communities in the field of mangrove tourism in Batu Karas Village, which is by moving all levels of society from the Youth, Community and Village level through life skills and soft skills training activities. Life skill activities are carried out through the Village Creative Economy Empowerment. The activity is managed and driven by the village government and Youth Organization as the leading sector in its implementation. Youth Organization has an essential role because it is they who carry out creative economic activities, in the form of typical beach souvenirs, be it key chains, shirts, and the like.

Strategies undertaken by local governments are the efforts to develop community in the field of marine and beach tourism in the village of Batu Karas. In the field of community development in the field of tourism, the government, in this case, is concerned with human resources as the implementer, while in other fields, the government is making improvements to infrastructure, including roads, tourist attractions, and bridges around the coast. Also, to improve the welfare of the surrounding community, the government implements regulations, namely user fees for mangrove sites, the results of which are for workers, and infrastructure improvements.

In the implementation of efforts to develop and empower communities in the field of mangrove tourism in Batu Karas Village, the local government continues to pay attention and follow the existing regulations, namely rules on tourism and marine affairs. The government also pays attention to all instruments that support the acceleration and development of community empowerment, both soft skills, and hard skills, as capital that must be owned by Batu Karas villagers through training.

What is encouraging is that there is awareness on the part of tourism residents that mangroves are not a place where they make a living. Nevertheless, mangroves must also be maintained in the context of preserving nature and protecting them from various disasters that often arise from the sea, such as tsunamis or tidal waves. The maintenance has now become a community culture around the location of mangrove tourism. In addition to natural and ecological culture, local culture is also maintained by holding local cultural products as well as local special activities such as traditional ceremonies, which can all be enjoyed by tourists as the mangrove community's uniqueness.

\section{REFERENCES}

Abdul, K. (2018). Tourism and Development: Land Acquisition, Achievement of Investment and Cultural Change (Case Study Tourism Industry Development In Batu City, Indonesia). GeoJournal of Tourism and Geosites, 21(1), 253. https://doi.org/10.30892/gtg.21120-285

Adriansyah, D., Busu, I., Eva, H., \& Muqtada, M. (2015). Geoheritage as the Basis of Geotourism Development: A Case Study in Jeli District, Kelantan, Malaysia. GeoJournal of Tourism and Geosites, 15(1), 25-43. 
Anderson, M.B., \& Woodrow, P.J. (2019). Rising from the ashes: development strategies in times of disaster. Routledge.

Bankoff, G. (2013). Mapping Vulnerability:" Disasters, Development and People". Routledge.

Barbieri, C., Santos, C.A., \& Katsube, Y. (2011). Volunteer Tourism: On-the-ground Observations from Rwanda. Tourism Management, 33(3), 509-516. https://doi.org/10.1016/j.tourman.2011.05.009

Bernard, H. R., Wutich, A., \& Ryan, G.W. (2016). Analyzing Qualitative Data: Systematic Approaches. SAGE publications.

Bittar Rodrigues, C., \& Prideaux, B. (2018). A Management Model to Assist Local Communities Developing Community-Based Tourism Ventures: A Case Study from the Brazilian Amazon. Journal of Ecotourism, 17(1), 1-19. https://doi.org/10.1080/14724049.2017.1309045

Bookchin, M. (2007). Social Ecology and Communalism. AK Press Oakland.

Bryson, J.M. (2018). Strategic Planning for Public and Nonprofit Organizations: A Guide to Strengthening and Sustaining Organizational Achievement. John Wiley \& Sons.

Cohen, E., \& Cohen, S.A. (2012). Current Sociological Theories and Issues in Tourism. Annals of Tourism Research, 39(4), 2177-2202. https://doi.org/10.1016/j.annals.2012.07.009

Corbin, J., \& Strauss, A. (2014). Basics of qualitative research: Techniques and procedures for developing grounded theory. Sage publications.

Corrêa Cavalieri, I., \& Neves Almeida, H. (2018). Power, Empowerment and Social Participation- the Building of a Conceptual Model. European Journal of Social Science Education and Research, 5(1), 174-185. https://doi.org/10.2478/ejser-2018-0020

D’Lima, C., Everingham, Y., Diedrich, A., Mustika, P.L., Hamann, M., \& Marsh, H. (2018). Using Multiple Indicators to Evaluate the Sustainability of Dolphin-Based Wildlife Tourism in Rural India. Journal of Sustainable Tourism, 26(10), 1687-1707. https://doi.org/10.1080/09669582.2018.1503671

Dian, A., I Gusti Putu, S., \& Slamet, S. (2018). Local Wisdom of Sabang Island Society (Aceh, Indonesia) in Building Ecological Intelligence to Support Sustainable Tourism. GeoJournal of Tourism and Geosites, 22(1), 393. https://doi.org/10.30892/gtg.22210-297

Eshun, G., \& Tichaawa, T.M. (2019). Reconsidering Participation for Local Community Well-Being In Ecotourism In Ghana. GeoJournal of Tourism and Geosites, 27(4), 1184-1200. https://doi.org/10.30892/gtg.27406-425

Gorbuntsova, T., Dobson, S., \& Palmer, N. (2019). Diverse geographies of power and spatial production: Tourism industry development in the Yamal Peninsula, Northern Siberia. Annals of Tourism Research, 76, 67-79. https://doi.org/10.1016/j.annals.2019.03.006

Kasdi, A., Farida, U., \& Cahyadi, I.F. (2019). Wali City Branding: Marketing Strategy in Promoting Halal Tourism Destinations Demak Indonesia. GeoJournal of Tourism and Geosites, 25(2), 463-473. https://doi.org/10.30892/gtg.25215-373

Mauricio, C.F., Marival, S.O., \& Conrado, C.-L. (2019). Motivations Analysis in Ecotourism Through an Empirical Application: Segmentation, Characteristics and Motivations of The Consumer. GeoJournal of Tourism and Geosites, 24(1), 48-59. https://doi.org/10.30892/gtg.24106-343

Miller, M.L., \& Kirk, J. (1986). Reliability and validity in qualitative research. Sage Publications.

Monteiro, P.V., \& de Noronha, T. (2020). Sustainable Development of Fisheries Communities: The Role of Community-Led Local Development Policies. In Regional Intelligence (49-72). Springer International Publishing. https://doi.org/10.1007/978-3-030-36479-3_4

Neuman, W.L. (2014). Basics of Social Research: Qualitative and Quantitative Approaches, 3rd Edition. Pearson.

Patrício, J.T.D. (2018). Lisbon's Web Summit: an event and tourism impact study [Católica-Lisbon School of Business \& Economics]. http://hdl.handle.net/10400.14/25378

Perbawasari, S., Sjuchro, D.W., Setianti, Y., Nugraha, A.R., \& Muda, I. (2019). Halal Tourism Communication Formation Model in West Java, Indonesia. GeoJournal of Tourism and Geosites, 25(2), 309-320. https://doi.org/10.30892/gtg.25203-361

Privitera, D., Nedelcu, A., \& Nicula, V. (2018). Gastronomic and food tourism as an economic local resource: Case studies from Romania and Italy. GeoJournal of Tourism and Geosites, 21(1), 143-157. http://gtg.webhost.uoradea.ro/PDF/GTG-1-2018/276_Nedelcu.pdf

Santoso, A.B., Kurniawan, E., \& Syifauddin, M. (2019). The Development Of Eco-Edutourism Village In Mangrove Tapak Forest Area, Tugurejo, Tugu SubDistrict As A Community-Based Tourism. Proceedings of the International Conference on Rural Studies in Asia (ICoRSIA 2018). https://doi.org/10.2991/icorsia-18.2019.79

Scheyvens, R., \& Hughes, E. (2019). Can Tourism Help to "End Poverty in all Its Forms Everywhere"? The challenge of Tourism Addressing SDG1. Journal of Sustainable Tourism, 27(7), 1061-1079. https://doi.org/10.1080/09669582.2018.1551404

Sen, V., \& Walter, P. (2020). Community-based Ecotourism and the Transformative Learning of Homestay Hosts in Cambodia. Tourism Recreation Research, 1-14. https://doi.org/10.1080/02508281.2019.1692171

Sprague, T. (2019). Conversing with Island Mangroves: Towards a New Story of Humanity's Relationship with the Earth. University of Bristol. https://research-information.bris.ac.uk/ws/portalfiles/portal/215121965/Sprague_Thesis_Final_Corrected_01112019.pdf

Tayyiba, M. (2015). Indonesia Broadband Plan: Lessons Learned. In Economic Competitiveness of Zones Coordinating Ministry for Economic Affairs. https://www.itu.int/en/ITU-D/Regional-Presence/AsiaPacific/Documents/Events/2015/Sep-WABA/Presentations/Indonesia Broadband Plan (ITU Jakarta, 090915).pdf

Tribe, J. (2015). The Economics of Recreation, Leisure and Tourism. Routledge.

Zamenopoulos, T., Lam, B., Alexiou, K., Kelemen, M., De Sousa, S., Moffat, S., \& Phillips, M. (2019). Types, Obstacles and Sources of Empowerment in CoDesign: The Role of Shared Material Objects and Processes. CoDesign, 1-20. https://doi.org/10.1080/15710882.2019.1605383

Zohreh, F., \& Syed Mohammad, R. (2018). Analysing the Urban Environment Sustainability Influenced by Tourism in Iran (District 1 of Tehran Metropolis). GeoJournal of Tourism and Geosites, 23(3), 719. https://doi.org/10.30892/gtg.23308-322

*** Batu Karas Village Government. (2020). Profile of Batu Karas Village.

*** Pangandaran Regency Government. (2020). Profile of Pangandaran Regency.

Article history: Received: $30.04 .2020 \quad$ Revised: 24.06.2020
Available online: 03.08.2020 